\title{
Village Head Leadership and Bureaucratic Model Towards Good Governance in Sidenreng Rappang
}

\author{
Ahmad Mustanir ${ }^{1}$, Kittisak Jermsittiparsert ${ }^{2}$, Akhwan Ali $^{3}$, \\ Sam Hermansyah $^{4}$, Sakinah ${ }^{5}$ \\ \{ahmadmustanir74@gmail.com¹, kittisak.j@chula.ac.th², alitribun@gmail.com³ \\ syam_hermansyah85@yahoo.com ${ }^{4}$, sakinahina68@gmail.com ${ }^{5}$ \} \\ University of Muhammadiyah Sidenreng Rappang, Indonesia ${ }^{1,3,4,5}$, \\ Social Research Institute, Chulalongkorn University, Bangkok Thailand ${ }^{2}$
}

\begin{abstract}
The leadership of Village Head and his quality of services at Lautang Benteng Office are less than optimal. The head of the village is not maximized in set of employees on time in delivering community services. Likewise, in carrying out its functions, namely the functions of control that has not been done effectively and efficiently is to conduct supervision and direction to employees' daily activities. Some of the clerks in Office. They are not fair in providing public services. Employees more quickly serve on relatives or nepotism such as the management of administration. Employees more quickly serve relatives near and among the economic upper class in comparison with the economic lower class. It was caused because the leadership of the headman are not optimal to perform its duties and functions in regulating and supervising, controlling the employees especially in service to the community.
\end{abstract}

Keywords: Bureaucratic Model, Good Governance, Leadership

\section{Introduction}

A leader is an important thing in organizing the needs of the community in their region. The leader also has a role to provide direction and give real influence on the subordinates or employees in carrying out the functions of an agency. Leadership is the ability to influence a group towards the achievement of the goal. The bureaucracy is an important instrument in modern society, its existence is not inevitable as a logical consequence of the main task of the government to carry out public welfare (social welfare) as in the public service. quality Service is one manifestation of the implementation of the principles of good governance. The leadership of Village Head and his quality of services at Lautang Benteng Office are less than optimal. The head of the village is not maximized in set of employees on time in delivering community services. Likewise, in carrying out its functions, namely the functions of control that has not been done effectively and efficiently is to conduct supervision and direction to employees' daily activities. Some of the clerks in Office. They are not fair in providing public services. Employees more quickly serve on relatives or nepotism such as the management of administration. Employees more quickly serve relatives near and among the economic upper class in comparison with the economic lower class. It was caused because the leadership of the headman are not optimal to perform its duties and functions in regulating and supervising, controlling the employees especially in service to the community. 


\section{Research Method}

The research method employed was descriptive quantitative. It used Random Sampling technique with a total sample of 96 respondents. Data collection techniques employed were observation, questionnaire, and documentation [1] [2]. Data analysis were by presenting data for each variable under study, performing calculations to answer the problem statements. The results of analysis employed quantitative descriptive techniques with frequency tables and used scale as a measuring instrument. The collected data employed analysis with SPSS 16.0 for Windows.

The analysis is based on functional or causal relationships. Statistically, measurements were made from statistical value $f$, statistical value $t$, and coefficient of determination. Statistical F test was used to indicate whether or not variable $\mathrm{X}$ entered has a joint effect on the variable $\mathrm{Y}$. The statistical value $\mathrm{f}$ is called significant if the value of $\mathrm{f}$-count $>\mathrm{f}$-table and test of significance of $0.05>$ sig. The "t" statistical test was used to determine whether or not there is a partial effect of $X_{1}$ and $X_{2}$ variables on variable $Y$. The calculation of statistical value $t$ is called significant if the statistical test is in a critical area ( $\mathrm{H}_{0}$ is rejected), and is not significant if the statistical test value is in the area where $\mathrm{H}_{0}$ is accepted. Or by associating the level of significance $t$ with $0.05(\mathrm{a}=5 \%)$ or comparing between $\mathrm{t}$ count with $\mathrm{t}$ table. If the significance level is $<0.05$ or if the t-count value $>\mathrm{t}$-table, the hypothesis is accepted. The coefficient of determination was used to measure how far the model's ability to explain the dependent variables. Determination coefficient value between 0 and 1.

\section{Result and Discussion}

\subsection{Village Head Leadership}

Table1. Recapitulation of respondents on Village Head Leadership

\begin{tabular}{clcc}
\hline No & Respondents & Average & Category \\
\hline 1 & Democratic & $70,4 \%$ & Good \\
2 & Bureaucratic & $68,2 \%$ & Good \\
3 & Freedom & $64,2 \%$ & Good \\
4 & Autocratic & $57,2 \%$ & Enough \\
& & Average $\frac{260 \%}{4}=65 \%$ & Good \\
\hline
\end{tabular}

Source: Questionnaire Data Processing,2019

The average accumulation of the percentage of four questions on the leadership style indicator, so that average percentage is obtained, which is $65 \%$ in the "Good" category. From the four indicators of leadership style, most dominant is the indicator of democratic which is $70.4 \%$, it means that Village Head in prioritizing the division of tasks to the staffs is categorized as good category. However, it still needs to be optimized and also the commands given to staffs should be based on their abilities / expertise in working on mandate given. However, the lowest is autocratic style with a value of $57.2 \%$, meaning that Village Head in treating employees depends on the power possessed which is considered to be fairly good category. 
In previous studies by [3] who obtained $69,97 \%$ with the category of "Influential". While the study of [4] of the four indicators of leadership style, the more dominant is the bureaucratic style to obtain the result is $83.6 \%$ belongs to the category of "Very Good" and the results of the research [5] [6] [7] show the influence of more dominant on the indicators of democratic style. So, indicator of the style of democratic style, bureaucratic style, freedom and style autocratic can be said to be influential to the realization of good governance, because of all a recapitulation of the research to get the same results, namely the effect. From this research means the Leadership in the Lautang Berteng Village the has been able to run all the indicators of leadership style with the good because included in the category of Good against the embodiment of good governance.

Based on the description above, it can be stated that this study with [3] because each researcher see the village chief from a perspective that is similar. when the village chief to perform the duties and functions as a leader. In line with the research Haeruddin where the most dominant, namely the democratic style in accordance with what was found in this study, and also this research same with research by [8] where it is found that at the time the author is doing an interview with the secretary of the headman in the Office of the Village Lubuk Pakam I-II on April 21, 2016 states that "the Headman of using democratic style to carry out his duties, so the motivation of subordinates can be improved then the leader should be able to apply leadership according to the situation and existing conditions". While this research is different from research [4] because in the background of the problem it was found that community participation in the implementation of development programs is still not good, which is shown by the existence of a problem-a classic problem that often occurs in people with no active members of the community following each meeting and activity of deliberation. This shows that the sub-district government is not able to embrace the community participate in these events. So, it can be stated headman as the helm of the government of the village should be able to mobilize the people in each of the activities, but the above phenomenon shows that the low mass mobilization by the village chief.

\subsection{Bureaucratic Style}

Table 2. Recapitulation of Respondents' Responses

\begin{tabular}{clcc}
\hline No & \multicolumn{1}{c}{ Respondents } & Average & Category \\
\hline 1 & Politeness & $64 \%$ & Good \\
2 & Justice & $54,4 \%$ & Enough \\
3 & Care & $58,6 \%$ & Enough \\
4 & Discipline & $63,6 \%$ & Good \\
5 & Sensitivity & $60,4 \%$ & Enough \\
6 & Responsibility & $61,4 \%$ & Good \\
& \multicolumn{2}{c}{ Average $\frac{362.4 \%}{6}=60,4 \%$} & Enough \\
\hline \multicolumn{2}{c}{ Source: } & Questionnaire Data Processing,2019
\end{tabular}

The accumulation of average percentage, which is $60.4 \%$, is category of "Good Enough". From six indicators of bureaucratic behavior, the most dominant is politeness, which is $64 \%$, it means that the motivation of staffs to serve community has been able to facilitate good and polite behavior by respecting the community. Nevertheless, the lowest is justice indicator with a value of $54.4 \%$. This value represents based on the time of the initial observation, where the 
staffs prefer to quickly serve their close relatives or being nepotistic, such as certificate or cover letter processing. This phenomenon needs to be adjusted by Government in terms of services to the community in order that the public perspective on the services provided by Government is fair.

For the indicators are both the concern, according to [9] in his book entitled "the Pathology of the Bureaucracy" states that justice is a behavior that does not discriminate who who are faced.

Summary the behavior of the bureaucracy in Lautang Benteng Village, Maritengngae District, Sidenreng Rappang Regency is $60 \%$ with the category of "Enough". If compared with the results of previous research, which was conducted by [3] shows that on indicators of justice and sensitivity to obtain a higher yield from this research. According to research [10] states that of these two indicators obtained a higher yield of some of the indicators of the behavior of the bureaucracy. While in the research [11] to get the same results on the indicator of concern in this study. As for the indicators of the behavior of the bureaucracy that is included in Good category to the realization of good governance is an indicator of decency, discipline and responsibility, while indicators of fairness, caring and sensitivity is included in the category quite Well. From this study the mean behavior of the bureaucracy to the realization of good governance to get the results of the $60 \%$ categorized well enough.

Based on the description above, it can be stated that this study is different with the research of [10] where it was found that on indicators of justice and sensitivity to obtain a higher yield from this study because the phenomenon that occurs at the time of the implementation of the public services, some government officials behave unfair in providing service to the community. As for the research [12] different with this research because in this research the view of service health center where the officer carrying out the functions of the service not in accordance with his expertise, the bureaucracy in the division of work tasks not decompose well. Job description as a guideline to carry out the duties of the ministry less clear, leaders do the delegation of tasks only on specific people so that the less appropriate designation, as a result the responsibility of officials sometimes look weak. Such a state is caused by the lack of "coordination" in both internal and external, in the sense that the element of lack of leadership to do the communication directly to the elements of the apparatus of the subordinates and to the public as a partner. While this research together with research [11] especially on indicators of concern because it was found that the apparatus of the government less concerned about what is required of the local community.

\subsection{Good Governance}

Table 3. Recapitulation of respondents of Good Governance

\begin{tabular}{clcc}
\hline No & Respondents & Average Percentage & Category \\
\hline 1 & Accountability & $57,2 \%$ & Enough \\
2 & Transparency & $57,4 \%$ & Enough \\
3 & Openness & $56,2 \%$ & Enough \\
4 & Rule of law & $65 \%$ & Good \\
& & Average $\frac{235.8 \%}{4}=58,95 \%$ & Enough \\
\hline
\end{tabular}

Source: Questionnaire Data Processing,2019 
The accumulation of average percentage 58.95\% category of "Good Enough". Of four indicators of good governance, the most dominant is legal rule indicator, which is $65 \%$, meaning that there are still activities that have a legal basis but have not been carried out by the Village government so that the Village government needs to review these activities. Whereas the lowest indicator of openness is $56.2 \%$. those present at the event did not represent the whole community.

Indicator the second is transparency, according to [13] transparency is a good governance will be transparent to its people, both at central and local levels. Results summary for good governance in Lautang Benteng Village, Maritengngae District, Sidenreng Rappang Regency. results obtained $59 \%$ which is categorized "enough". If compared with previous research, which was done by [14] get the result of $69,4 \%$ is categorized as good. While the study [15] of the five indicators of good governance, get the most low namely on indicators of accountability of some of the indicators and the results of the research [16] have the same result with this research on indicators of Accountability, namely the category of pretty good. From this research it means good governance in Lautang Benteng Village,has been applying all these indicators, but still enough category.

Based on the description above, it can be stated that this research is different from that done by [14] as seen from the difference in the theory used to measure good governance, where the theory used by [14] is the theory of good governance proposed by [17] that has a measurement indicator, i.e. accountability, transparency, openness, rule of law and a guarantee while in this study using the theory proposed by [13] with indicators of accountability, transparency, openness and the rule of law. As for the research conducted by Verawati the same with this research because of the theory of the use of such research is similar to the theory in use by researchers which use the theory proposed [13] and the assessment community on the government acting as the party responsible for the policies that have been set to realize the good governance is in the category of enough. Then research [15] in contrast to that done by researchers where it was found that the research on the indicators of accountability to obtain the results of the most low from some indicators of the other because of the results of the interviews have been conducted by researchers with the Head of Field Implementation of Licensing Services. He stated that: "the Principles of good governance expected in the office is already running, but has not been realized to the maximum because the principle of accountability or responsibility in this office have not been good so hinder the achievement of the desired goal". In line with the research [18] found that the readiness of the central government and the local government has been good in the implementation of in welcoming the Law No. 14 of Village. Live how the readiness of the government of the village in planning budgets, implement budgets, evaluation and accountability of the management of the funds of the village. In order to support the realization of good governance in the implementation of the village, village financial management is conducted based on the principle of governance that is transparent, accountable and participatory and conducted in an orderly and disciplined budget. 


\subsection{Village Leadership and Bureaucratic Behavior Towards the Realization of Good Governance}

Table 4. Model of Summary

\begin{tabular}{llrrr}
\hline Model & R & R Square & Adjusted R Square & \multicolumn{2}{c}{$\begin{array}{c}\text { Std. Error of the } \\
\text { Estimate }\end{array}$} \\
\hline 1 & $.106^{\mathrm{a}}$ & .011 & -.010 & 1.768
\end{tabular}

a. Predictors:(Constant),Bureaucratic Behavior,Village Leadership

Based on the result above, it explains that magnitude of correlation / relationship (R) is 0.106 and is explained by percentage effect of variables $\mathrm{X} 1, \mathrm{X} 2$ on $\mathrm{Y}$ which is called coefficient of determination which is the result of $\mathrm{R}$. from output coefficient of determination (R Square) amounting to 0, 011, which implies that influence of Village Leadership and Bureaucratic on the Realization of Good Governance is $11 \%$ while the rest is influenced by other factors.

Table 5. Anova

\begin{tabular}{lccccc}
\hline Model & $\begin{array}{c}\text { Sum of } \\
\text { Squares }\end{array}$ & df & Mean Square & F & Sig. \\
\hline 1 Regression & 3.287 & 2 & 1.643 & .526 & $.593^{\mathrm{a}}$ \\
Residual & 290.703 & 93 & 3.126 & & \\
Total & 293.990 & 95 & & & \\
a. Predictors:(Constant),Bureaucratic Behavior,Village Leadership & \\
b. Dependent Variable: Good Governance & & & \\
\end{tabular}

The table above explains whether there is a significant (significant) influence of Village leadership (X1) and bureaucratic (X2) on good governance (Y) variables. From the results of the calculation above, it can be seen that $\mathrm{F}$ count $=0.526$ with a significant level of probability of $0.593>0.005$, then the regression model can be used to predict the variable good governance. 
Table 6. Coefficients

\begin{tabular}{|c|c|c|c|c|c|}
\hline \multirow[b]{2}{*}{ Model } & \multicolumn{2}{|c|}{$\begin{array}{l}\text { Unstandardized } \\
\text { Coefficients }\end{array}$} & \multirow{2}{*}{$\begin{array}{c}\begin{array}{c}\text { Standardized } \\
\text { Coefficients }\end{array} \\
\text { Beta }\end{array}$} & \multirow[b]{2}{*}{$\mathrm{T}$} & \multirow[b]{2}{*}{ Sig. } \\
\hline & $\mathrm{B}$ & Std. Error & & & \\
\hline 1 (Constant) & 12.749 & 1.470 & & 8.674 & .000 \\
\hline $\begin{array}{l}\text { Bureaucratic } \\
\text { Behavior }\end{array}$ & .024 & .072 & .034 & .328 & .744 \\
\hline $\begin{array}{l}\text { Village } \\
\text { Leadership }\end{array}$ & .068 & .068 & .104 & 1.004 & .318 \\
\hline
\end{tabular}

The table above explains that in column B at constant (a) is 12.749 while the leadership score of Village (b1) is 0.024 and the value of bureaucratic behavior (b2) is 0.068 . Based on the data above, it can be said that:

a. Constant from the Unstandardized Coefficients, the value is 12.749 , which means that if there is Village leadership (X1) and bureaucratic (X2), the value of good governance $(\mathrm{Y})$ is 12.749 .

b. Regression coefficient X1 equals 0.024 means that every $1 \%$ increase in Village leadership value, good governance (Y) will increase by 0.024

c. The regression coefficient $\mathrm{X} 2$ of 0.068 means that for every $1 \%$ increase in the value of bureaucratic, good governance (Y) will increase by 0.068 .

Based on the table above, it can be seen that the leadership variable obtains t count $=0.328$ with a significant value of $0.744>0.5$, meaning that there is a significant effect while the bureaucratic variable obtains $t$ count $=1.004$ with a significant value of $0.318>0.5$ meaning that there is a significant influence. It means that there is a significant (significant) influence of Village leadership (X1) and bureaucratic (X2) on good governance (Y) variables.

\section{Conclusion}

Village leadership includes four leadership, namely democratic, bureaucratic, freedom and autocratic. The results of indicators regarding Village leadership with $65 \%$ achievement included the good category. Bureaucratic includes politeness, justice, caring, discipline, sensitivity and responsibility. The results of indicators of bureaucratic with achievement of $60.4 \%$ in the fairly good category. Good governance includes four indicators including accountability, transparency, openness and rule of law. The four indicators, $58.95 \%$ were included in the fairly good category. The Village leadership obtained a $t$ count $=0.328$ with a significant value of $0.744>0.5$ while the bureaucratic variable obtained a t count $=1.004$ with a significant value of $0.318>0.5$ with a percentage $11 \%$, it can be said that there is a significant influence between the village leadership variable and bureaucratic towards the realization of good governance. The better village leadership and bureaucratic will increase the realization of good governance. 


\section{References}

[1] Sugiyono.: Quantitative Research Methods, Qualitative and R\&D. Bandung: PT Alphabeta (2016)

[2] Ahmad, J.: Research Methods Of Public Administration. Yogyakarta: Gava Media (2015)

[3] Gafur, A.: "The Influence of Leadership Behavior and the Bureaucracy to the Realization of Good Governance in the Village Lancarang District of Pitu Riawa district Sidenreng Rappang," STISIP Muhammadiyah Rappang (2016)

[4] Andriani, D.: "The Characteristics of the Leadership of the Headman of Community Participation in the Development Planning Meeting in Duampanua, Baranti District, Sidenreng Rappang Regency," STISIP Muhammadiyah Rappang (2018)

[5] Syarifuddin, H.: "The Leadership Style of the Head of the Village Towards the Improvement of the Welfare of the Community in the Village Timoreng Panua Regency of Sidenreng Rappang," Vol. 1, no. 1 (2015)

[6] Mustanir, A and Lubis, S.: "Participatory Rural Appraisal in Deliberations of Development Planning," in International Conference On Democracy, Accountability, and Governance (ICODAG 2017), Vol. 163, no. Icodag, pp. 316-319 (2017)

[7] Mustanir, A., Abadi, P., and Nasri, A.: "Participation of Ethnic Community Towani Tolotang in Deliberation of Development Plan," in International Conference on Ethics in Governance (ICONEG 2016) Vol. 84, pp. 356 - 359 (2016)

[8] Arianto, B.: "The Leadership of the Headman in Improving the Work Motivation of the Village," J. Public Adm. (Public Adm. Journal), vol. 6, no. 2, pp. 107-122 (2016)

[9] Siagian, S.P.: Human Resource Management, Leadership and the Behavior of the Administration. Jakarta: Bumi Aksara (1994)

[10] Rodding, M.I.: "The Influence of Leadership Behavior and the Bureaucracy on the Performance of Employees In District Office Maiwa Kabupaten Enrekang,” STISIP Muhammadiyah Rappang (2016)

[11] Oktamiati.: "No The Public Perception of the Behavior of the Bureaucracy in Kelurahan Kadidi Kecamatan Panca Rijang Kabupaten Sidenreng Rappang," (2017)

[12] Hamzah, O. S.: "No TitleThe Behavior of The Government Bureaucracy In The Service Of Puskesmas In Makassar City,” Sci. J. Sci. Public Adm., Vol. 4, no. 1(2014)

[13] Sedarmayanti.: Good Government (Good Governance). Bandung: CV Mandar, (2004)

[14] Pratama, M. Y.: "Community Participation in the Development Plan Meeting (MUSRENBANG) to Realize Good Governance in the Village Karueng District Enrekang Kabupaten Enrekang,” Muhammadiyah Sidenreng Rappang University (2018)

[15] Saad, D. A.: "The influence of the Principles of Good Governance to the Effectiveness of the Administrative Services Letter of Trade Business License At the Office of the Department of Investment Services of the One Stop Enrekang Regency," Muhammadiyah Sidenreng Rappang University (2018)

[16] Verawati.: "The Effect of Leadership and Community Participation on Good Governance in Mattirotasi Village, Wattang Pulu District, Sidenreng Rappang Regency,” (2017)

[17] Mustanir, A., Ali, A., and Yasin, A.: "Transect on Participatory Development Planning in Sidenreng Rappang Regency," in IOP Conference Series: Earth and Environmental Science (2018)

[18] Yulianto T. E. P., Astuti.: "Good Governance Financial Management Of The Village To Welcome The Entry Into Force Of Law No. 6 Tahun 2014,” Account. Financ., Vol. 1 (2016) 